\title{
1999 Depremlerinin Ardından Planlama Mevzuatı Üzerine Bir Değerlendirme
}

\section{An Evaluation on Planning Legislation Following the 1999 Earthquakes}

\section{Ezgi Orhan}

Çankaya Üniversitesi Mimarlık Fakültesi, Şehir ve Bölge Planlama Bölümü, Ankara

\section{ÖZ}

Ülkenin nüfusu en yüksek, en kentleşmiş ve sanayileşmiş bölgesi olan Marmara Bölgesi'nde yaşanan 1999 Depremlerinin ardından geniş ölçekli iyileştirme çalışmaları başlatılmış, merkezi ve yerel yönetimlerin yanı sıra pek çok kurum ve sivil toplum bu çalışmaların parçası haline gelmiştir. Ancak, 1999 Depremlerinin yıkıcı etkileri karşısında afet politikalarını yönlendiren yasal çerçevenin kısıtlılı̆ı anlaşıldığından bu alanda önemli adımlar atılmıştır. Öte yandan, uluslararası düzeyde risk yönetimini benimseyen bir yaklaşım gelişmesi, ülkeleri afet yönetimlerini biçimlendiren politikalarını ve yasal düzenlemelerini gözden geçirmeleri gerekliliğini tetiklemiştir. Bu ihtiyaçtan hareketle çalışma, ülkemizdeki afet politikalarını şekillendiren mevzuatı ve süreç içindeki değişimlerini mekansal planlamayı nasıl yönlendirdiğini incelemektedir. Risk azaltma amacıyla son 20 yılda kentsel planlama mevzuatına eklenen yasal düzenlemelerin neler olduğu, amaç ve kapsamları ele alınmıştır. Bu doğrultuda, 5393 sayılı "Belediye Yasası"nın 73. Maddesi, 5366 sayılı "Yıpranan Tarihi ve Kültürel Taşınmaz Varlıkların Yenilenerek Korunması ve Yaşatılarak Kullanılması Hakkında Kanun”, 6306 sayılı "Afet Riski Altındaki Alanların Dönüştürülmesi Hakkında Kanun” ve 3194 Sayılı “İmar Kanununun Geçici 16. Maddesi (İmar Barışı)" kentsel riskleri azaltma politikalarını biçimlendiren ana düzenlemeler olup, çalışma kapsamında değerlendirilmiştir. Bu çalışma, yıkım gören alanların iyileştirilmesinin yanı sıra kentsel riskleri azaltma amacıyla oluşturulan yasal düzenlemelerin uygulanmasına ilişkin sorunlar ve eleştirileri ortaya koymaktadır.

Anahtar sözcükler: Afet planlaması; afet riski azaltma; planlama mevzuatı.

\begin{abstract}
Following the 1999 Earthquakes stricken Marmara Region, as the most populated, urbanized and industrialized region of the country, large-scale recovery efforts have been initiated; and in addition to central and local administrations, many institutions and civil societies have become the part of these studies. However, in the face of the devastating effects of the 1999 Earthquakes, significant steps have been taken in legal framework due to its limitedness in guiding disaster policies. Besides, development of the risk management approach at the international level has triggered countries to review their policies and legal regulations shaping their disaster management. Based on this need, the study examines the legislation that shapes the disaster policies and guides spatial planning in our country and its change in the meantime. The legal regulations that have been added to the urban planning legislation in the last 20 years for the purpose of risk mitigation have been discussed. To this end, Article 73 of the "Municipality Law" (no. 5393), "Law on Conservation of Deteriorating Historic and Cultural Property through Renewal and Re-use" (no. 5366), "Law on the Transformation of Areas at Disaster Risk" (no. 6306), and Temporary Article 16 of Development Law (no. 3194) (Peace of Reconstruction) are determined as the main regulation shaping policies for reducing urban risks, and evaluated within the scope of the study. Therefore, this study puts forward the problems and criticisms regarding the implementation of legal arrangements established for the purpose of mitigating urban risks as well as recovery of the disaster-prone areas.
\end{abstract}

Keywords: Disaster planning; disaster risk reduction; planning legislation.

Geliş tarihi: 09.06.2020 Kabul tarihi: 24.04.202I

Online yayımlanma tarihi: 25.05.202I

İletişim: Ezgi Orhan

e-posta: ezgiorhan@cankaya.edu.tr 


\section{Giriş}

Doğal tehlikeler karşısında kentlerin sosyal, ekonomik ve fiziksel sistemlerinin kırılganlıkları kentsel riskleri oluşturur. Diğer bir ifadeyle, kentsel riskler, fiziki çevrenin yanı sıra tarihsel, sosyal ve ekonomik yapıların doğal afetlere karşı kırılganlığını ifade eder. Doğal tehlikelere maruz yerleşimlerde, tarihsel süreçte oluşan sosyo-ekonomik yapının kırılganlığı kentsel riskleri meydana getirir (Orhan, 2016). Kentsel risklerin azaltımını hedefleyen politikaların afet yönetiminin temel prensibi olarak görülmesi, mekansal planlamanın ve kentleşmeye ilişkin kararların da biçimlenmesinde bağlayıcı olacaktır. Bu bakımdan, risk azaltımının temel ilke olarak benimsendiği bir politik ortamda, afete maruz yerleşimlerin planlanmasında, plan kararlarında belirleyici ve sınırlandırıcı rolü olan yasal zeminin gelişmiş olması beklenir.

Ülkemizin deneyimlediği 1999 Depremleri fiziksel, ekonomik ve sosyal açılardan derin sarsıntılara sebep olmakla birlikte afetlere ilişkin yönetim anlayışının değişiminde de önemli bir yol ayrımı yaratmıştır. Gerek kentsel planlamayı yönlendiren gerekse afet yönetimini biçimlendiren yasal zemin ve kurumsal örgütlenme yeniden yapılanmıştır. Bu bağlamda, bu çalışmanın amacı 20 yılın ardından kentsel riskleri azaltmayı sağlayıcı politikaları şekillendiren yasal mevzuattaki değişimleri incelemektedir. Bunun için öncelikle planlamayı yönlendiren yasal düzenlenmelere ilişkin yazın taraması sunulmuştur. Bir sonraki bölümde, çalışmanın çıkış noktasını da oluşturan 1999 Depremleri öncesinde planlama mevzuatını da ilgilendiren afet yönetimine ilişkin yasal ve kurumsal düzenlemeler özetlenmiştir. Ardından, risk azaltma amacıyla son 20 yılda kentsel planlama mevzuatına eklenen yasal düzenlemelerin neler olduğu, amaç ve kapsamları ele alınmıştır. Sonuç bölümünde ise, Türkiye'de afet yönetimi anlayışının biçimlendirdiği yasal dayanakların planlamaya nasıl yön verebileceği ve beraberinde doğan sorulara değinilmiştir.

\section{Afet Riski Azaltımında Planlama ve Mevzuat}

Kentsel sistemlerin kırılganlıkları, ulusal ve politik ekonomik yapı, ekonomik gelişmişlik düzeyi, gelir dağılımı, demografik faktörler, toplumsal özellikler, sosyal ve kültürel politikalar, yasal haklar ve çevre koruma düzeyi gibi etkenlere göre değişmektedir (Bolin ve Stanford, 1998). Bu etkenler göz önüne alındığında, benzer doğal afet tehlikelerine sahip yerleşimlerde kentsel risklerin düzeyi, sistemlerinin dirençliliğine göre farkIılıklar gösterecektir. Diğer bir deyişle, farklı politik-ekonomik sistemlere sahip gelişmiş ve gelişmekte olan ülkelerde kentsel risklerin farklılaştı̆̆ı söylenebilir.

Afet yönetimi bakımından rasyonel bir risk azaltma yaklaşımının yerleşmesinde ve kentlerin dirençli hale gelmesinde ülkeler arasında farklılaşmalar bulunmaktadır. Smith ve Petley (2009) bu farklılaşmayı ülkelerin nüfus, doğum oranı, sahip olunan kaynak miktarı, kentlerin büyüklükleri, teknolojik dü- zeyleri, çevre güvenliği, ekonomik yapıları ve dışa bağımlılıkları ile ilişkilendirmektedir (Şekil I). İlk bakışta, gelişmiş ülkelerin kurumsallaşmış bir yapısının, dolayısıyla güçlü bir afet yönetimi kapasitesinin olduğundan söz edilebilir; buna karşın, gelişmekte olan ülkelerde afetlerin istenmeyen sonuçlarıyla başa çıkabilme politiğinin yerleştirilmesinin ve toplumun bunu kabul etmesinin kolay olmadığı ileri sürülebilir. Küresel ölçekte bu genellemeyi bozan örneklerin varlığına ve iyi uygulamaların giderek artmasına karşın, farklı ülkelerde afet politiğinin oluşumunda kentsel riskleri artıran benzer unsurlar bulunmaktadır.

Gelişmekte olan ülkelerde kentsel riskleri artıran ve birbirleriyle benzeşen kültürel, demografik ve politik unsurlar görülmektedir. Bunların başında hızlı kentsel nüfus artışı, kurumsal kapasitenin yetersizliği, bilgi, kapasite ve kaynak eksikliği ve afet hazırlıklarının yetersizliği, sanayinin tehlikeli coğrafyalarda yer seçimi, yasal olmayan konut alanlarının oluşması ve plansız kentleşme geldiği ileri sürülebilir. Kentsel riskleri artırıcı rol oynayan bu etkenler özellikle gelişmekte olan ülkelerin daha fazla korunmasız olmalarına ve afetlerin daha yıkıcı sonuçlarına yol açabilir.

Türkiye kentleri de, riskleri oluşturan etmenlere bakıldığında büyük risk havuzları olarak görülebilir. Bu durum, Balamir'e (20I2) göre tarihsel bir miras olan yerleşimlerin tehlike gösteren coğrafyalarda yer alması nedeniyle olduğu kadar, hızlı kentleşme ve çok katlı betonarme yapılaşmanın bir ürünüdür. Kentlerimizde riskleri artıran etkenler kaçak ve dayanıksız yapılaşmadan kaynaklandığı gibi yetersiz açık alanlar, gelişigüzel altyapı şebekeleri, düzensiz yapılaşma biçimi ve yüksek yoğunluklar, tehlikeli komşuluklar, acil durumlarda başvurulacak tesislerin dayanıksızlığı ve yanlış konumlandırılmaları, sanayi kuruluşlarının yer seçimi gibi fiziki düzenlemeler ile de doğrudan ilişkilidir. Bunlara ek olarak, yönetsel yetersizlikler ve yaygın toplumsal edilgenlik de kentsel riskleri artırıcı rol oynamaktadır (Orhan, 2016, 2018). Yerleşimlerde planlama disiplinine uygun olmayan uygulamalar yapılması ve kısa erimli ve tek seferlik çözümlere odaklanılması olası tehlikelerin getirdiği riskleri artırma potansiyeli taşımaktadır.

Afet risklerinin yoğunlaşması ve şiddetli yıkımlar, uluslararası kurumları, araştırmacıları ve ülkeleri koordineli olarak risk yönetiminde politik sorumluluk almaya yöneltmiştir. Özellikle, benzer tehlike türlerine maruz ülkeler arasında kırılganlık koşullarının farklılaşmasından dolayı risklerin değişkenlik göstermesi, müdahalenin mümkün olduğunu ve yönetimlerin harekete geçmeleri gerekliliğini göstermektedir. Müdahalelerin büyük kısmını afet sonrası koşullarda eyleme geçiren az gelişmiş ve gelişmekte olan ülkeler için, uygulanan politikaların yetersizliği 1980 lerden bu yana tartışılmaktadır. Balamir'e göre (2007, s. 32), "afetlerden sonra yapılan yardımlara gereksinmelerin aşırı büyümesi, yardım geri dönüşlerinin sınırlı kalması, tehlikelere karşı duyarsızlıkların ve risk alma eğilimlerinin giderek artması 1980'lerde 'yara sarma' politikalarının sorgulanmasına yol 


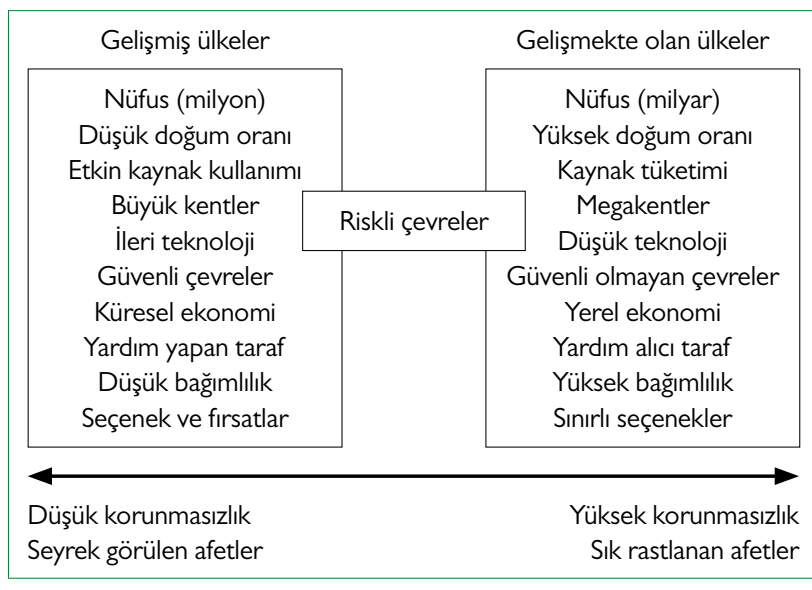

Şekil I. Korunmasızlık faktörleri açısından gelişmiş ve gelişmekte olan ülkelerin özellikleri.

Kaynak: Smith ve Petley, 2009'dan aktarım.

açmıştır". Afet sonrası kurtarma ve yardım operasyonları ile acil durum yönetimi konularına ağırlık veren geleneksel afet politikalarının yerini, öncülüğünü Birleşmiş Milletlerin yaptığı ve risk kavramı odaklı bir yaklaşım benimseyen çağdaş görüşler almıştır (Balamir ve Orhan, 20I2). Birleşmiş Milletler Afet Riski Azaltma Ofisi koordinasyonundaki uluslararası bir deklarasyon niteliği ve ülkelere afet riski azaltımında rehberlik etme nosyonu taşıyan Hyogo Çerçeve Eylem Planı'nın (HFA 2005-20I5) beş öncelikli eylem alanından ilki kurumsal ve politik kapasitenin geliştirilmesidir (UNISDR, 2005). Bu amaç doğrultusunda, ülke düzeyinde yasal ve yönetsel çerçevenin oluşturulması, gücün ve kaynakların desantralize edilerek aktörler arası yönetişiminin geliştirilmesi temel eylemler olarak tanımlanmıştır. HFA'nin ardından hazırlanan ve 20I5-2030 dönemindeki faaliyetlere rehberlik edecek olan Sendai Afet Riski Azaltma Çerçevesindeki dört öncelik alanından biri afet risk yönetişimi olarak belirlenmiştir. Sendai Çerçevesine göre, ülkelerin, ulusal ve yerel düzeyde kanun, yönetmelik ve kamu politikalarının şekillendirilmesi ve kamu ve özel sektörün afet riski azaltma eylemlerini yönlendirecek ve teşvik edecek rol ve sorumlulukları tanımlaması beklenmektedir (UNISDR, 20I5). Bu durumda, her iki deklarasyon da, afet yönetiminde risk azaltımını temele alan, yerel ihtiyaçları karşılayabilecek ve tabandan tavana biçimlenen bir mevzuata ihtiyaç olduğunu işaret etmektedir.

Günümüzde afet olgusuna ilişkin yaklaşımda, kent planları mekânsal kırılganlıkların ve afet riskinin azaltılmasındaki düzenleyici rolü nedeniyle afet risk yönetiminde önemli bir bileşen olarak görülmektedir. Planlamanın uygulamalarının gerçekleşmesinde planların dayanağını oluşturan mevzuatın afet riskleriyle başa çıkabilecek araçları sunması beklenir. Bu nedenle, salt plan kararları değil, planlama mevzuatının da afet risk yönetimini benimsemiş bir anlayışla hazırlanması ve dirençliliği benimseyen çağdaş afet paradigmalarına göre şekillenmesi ve güncellenmesi gerekmektedir.
Plan kararlarını yönlendiren mevzuatın temelinde çağdaş yaklaşımlar ışı̆ıında geliştirilen sakınım anlayışının bulunması beklenmektedir. Mekansal planlamanın ve afet sakınımının ortak paydasında sistemli ve kapsamlı bir yaklaşım, kamu yararı, uzun vadeli stratejiler ve hedefler, toplumsal kalkınma yer almaktadır (Godschalk vd., 1998). Kurumsal kapasite inşasının temel bileşenlerinden olan yasal çerçeve pek çok ülkede oluşum halindedir; afet risklerinin azaltılması hedefi mevcut yasal düzenlemelerin güncellenmesini ve ilave düzenlemelerin hazırlanmasını içerir (Rivera ve Wamsler, 20I4; Bang, 20I4).

Afet sakınımını benimseyen bir planlama yaklaşımının ana omurgasını kent ölçeği ve yapı düzeyinde geliştirilen önleyici politikalar, yapısal koruma, acil durum hizmetleri, doğal kaynak yönetimi ve teknik bilgi kullanımı oluşturmaktadır. Kentsel büyümenin istenmeyen alanlara yayılmasını engellemek, imara açılan alanlardaki eğilimleri düzenlemek, yapı yönetmelikleri ve altyapı standartları geliştirmek, tehlike alanlarında yoğun yapılaşmayı sınırlandırmak ve afet esnasındaki etkileri azaltmak için uyarı, tahliye, müdahale ve acil barınma olanaklarını sağlamak planlamanın müdahale alanları olarak görülmektedir (Burby vd., 200I). Bu bağlamda, planlama kararlarının öncelikleri tehlike alanları ve tehlike tipleri hakkında bilgi sunarak toplumu tehlikeli alanlarda yapılaşmanın maliyeti ve sonuçları hakkında uyarmak, uygun kentsel arazi kullanımları belirleyerek afetlere yönelik mekansal düzenlemeyi yapmak, karar vericiler için doğal afetleri diğer öncelikli konularla bağdaştırmaktır (Burby ve Dalton, 1994).

Yerel düzeyde uygulanacak planlarda, bu öncelikleri yönlendirecek mevzuatın oluşturulması gereklidir. Planlamaya ilişkin mevzuat, bir yandan doğrudan merkezi yönetim eliyle müdahale edilecek olan alan ve konuları, diğer yandan ise yerel yönetimleri yönlendirecek düzenlemeleri de kapsamaktadır (Dalton ve Burby, 1994). Özellikle, mekansal planlama için bağlayıcı olan mevzuatın, uluslararası örgütlerin desteklediği biçimde afet risklerini azaltmak üzerine kurulu bir anlayışla ve ülkelerin ve kentlerin yerel koşullarına uygun biçimde hazırlanması temel bir ihtiyaçtır. Bunların yanı sıra, Johnson (20I I) planlama ve arazi kullanımını yönlendirecek olan mevzuatın yerelin ihtiyaçlara uyumlanabilecek esneklikte stratejik ve öngörülü olması gerektiğini vurgulamaktadır. Tüm bu ilkeler gözetildiğinde, çalışma, ülkemizde yürürlüğe giren afet mevzuatının, kırılma noktası olarak kabul edilen 1999 Depremleri sonrasında nasıl biçimlendiğini ve mekansal planlamayı yönlendirirken hangi amaçları benimsediğini araştırmaktadır.

\section{Depremleri Öncesi Yasal ve Kurumsal Yapıya Genel Bir Bakış}

Afet mevzuatının temelini Osmanlılar Döneminde İstanbul'un imar düzenlenmesi için 1848'de çıkarılan "Ebniye Nizamnamesi” oluşturur. Cumhuriyet'in kuruluşunun ilk yıllarından 
Tablo I. 1999 depremleri öncesi afet yönetimine ilişkin kanun ve KHK düzeyindeki yasal düzenlemeler

\begin{tabular}{|c|c|c|}
\hline Tarih & Sayı & Kanun adı \\
\hline 1848 & - & Nafia Nezareti'nin kurulması (bayındırlık işleri) \\
\hline 1848 & - & Ebniye Nizamnamesi \\
\hline 1930 & 1580 & Belediye Kanunu \\
\hline 1933 & 2433 & Belediye Yapı ve Yolları Kanunu \\
\hline 1939 & 3611 & Nafıa Vekâleti teşkilât ve vazifelerine dair Kanun \\
\hline 1940 & 3773 & Erzincan'da ve Erzincan Depreminden Müteessir Olan Mıntıkalarda Zarar Görenlere Yapılacak Yapılar Hakkında Kanun \\
\hline 1943 & 4373 & Taşkın Sulara ve Su Baskınlarına Karşı Korunma Kanunu \\
\hline 1944 & 4623 & Yer Sarsıntılarından Evvel ve Sonra Alınacak Tedbirler Hakkında Kanun \\
\hline 1948 & 5243 & Erzincan'da Yaptırılacak Meskenler Hakkında Kanun \\
\hline 1950 & 5663 & Eskişehir Sel Baskınından Zarar Görenler İçin Yaptırılacak Meskenler Hakkında Kanun \\
\hline 1956 & 6746 & $\begin{array}{l}\text { Aydın, Balıkesir, Bilecek, Edirne, Eskişehir, Konya ve Denizli Vilayetlerinde Tabii Afetlerden Zarar Görenlere Yapılacak } \\
\text { Yapılar Hakkındaki Kanunlar }\end{array}$ \\
\hline 1956 & 6785 & İmar Kanunu \\
\hline 1958 & 7116 & İmar ve İskan Vekaleti Kuruluş ve Vazifeleri Hakkında Kanun \\
\hline 1958 & 7126 & Sivil Savunma Kanunu \\
\hline 1959 & 7269 & Umumi Hayata Müessir Afetler Dolayısıyla Alınacak Tedbirlerle Yapılacak Yardımlara Dair Kanun \\
\hline 1965 & & Afet İşleri Genel Müdürlüğü’nün kurulması \\
\hline 1971 & & Deprem Araştırma Enstitüsü Başkanlığı'nın kurulması \\
\hline 1985 & 3194 & İmar Kanunu \\
\hline 1992 & 3838 & $\begin{array}{l}\text { Erzincan, Gümüşhane ve Tunceli İllerinde Vuku Bulan Deprem Afeti ile Şırnak ve Çukurca'da Meydana Gelen Hasar ve } \\
\text { Tahribata ilişkin Hizmetlerin Yürütülmesi Hakkında Kanun }\end{array}$ \\
\hline 1995 & 4123 & Tabii Afet Nedeniyle Meydana Gelen Hasar ve Tahribata ilişkin Hizmetlerin Yürütülmesine Dair Kanun \\
\hline 1999 & 4452 & $\begin{array}{l}\text { Doğal Afetlere Karşı Alınacak Önlemler ve Doğal Afetler Nedeniyle Doğan Zararların Giderilmesi İçin Yapılacak } \\
\text { Düzenlemeler Hakkında Yetki Kanunu }\end{array}$ \\
\hline 1999 & 587 & Zorunlu Deprem Sigortasına Dair Kanun Hükmünde Kararname \\
\hline 2000 & 600 & $\begin{array}{l}\text { Başbakanlık Teşkilatı Hakkında Kanun Hükmünde Kararnamenin Değiştirilerek Kabulü Hakkında Kanunda Değişiklik } \\
\text { Yapılmasına Dair Kanun Hükmünde Kararname ile Türkiye Acil Durum Yönetimi Genel Müdürlüğü kurulması }\end{array}$ \\
\hline 2001 & 4708 & Yapı Denetimi Hakkında Kanun Hükmünde Kararname \\
\hline 2004 & 5216 & Büyükşehir Belediyesi Kanunu \\
\hline 2005 & 5302 & İ Özel İdaresi Kanunu \\
\hline 2005 & 5366 & Yıpranan Tarihi ve Kültürel Taşınmaz Varlıkların Yenilenerek Korunması ve Yaşatılarak Kullanılması Hakkında Kanun \\
\hline 2005 & 5393 & Belediye Kanunu \\
\hline 2009 & 5902 & Afet ve Acil Durum Yönetimi Başkanlığı'nın Teşkilat ve Görevleri Hakkında Kanun \\
\hline 2011 & 644 & Çevre ve Şehircilik Bakanlığı'nın Teşkilat ve Görevleri Hakkında Kanun Hükmünde Kararname \\
\hline 2012 & 6305 & Afet Sigortaları Kanunu \\
\hline 2012 & 6306 & Afet Riski Altındaki Alanların Dönüştürülmesi Hakkında Kanun \\
\hline
\end{tabular}

Kaynak: Aktel, 2010; Ergünay, 20II; Kemaloğlu, 2015; Kepenek ve Gençel, 2016; Tercan, 2018.

itibaren meydana gelen doğal afetlere karşı olaya ilişkin, akut ve afet sonrası zararı gidermeye yönelik çeşitli yasal düzenlemeler yapılmıştır (Tablo I). Ancak 1950lerin ikinci yarısından sonra afet planlamasına yön verecek yasal ve yönetsel yapılanma tüm ülke genelini gözetecek şekilde biçimlenmiştir. Bu dönemde, 1956'dan 1985 yılına kadar geçerli kalacak 6785 sayılı “İmar Kanunu” ve "Sivil Savunma Kanunu” yürürlüğe girmiştir. 15.05.1959 tarihinde çıkarılan ve bugün hala geçerli olan 7269 sayılı "Umumi Hayata Müessir Afetler Dolayısıyla Alınacak Tedbirlerle Yapılacak Yardımlara Dair Kanun”, başka bir deyişle "Afetler Kanunu" afet yönetiminin yasal çerçevesini oluşturmaktadır. Bu kanunla birlikte afet yönetimindeki temel kurumsal yapılanmalar şekillenmiş ve İmar ve İskan Vekaleti, Afet İşleri Genel Müdürlüğü ve Deprem Araştırma Enstitüsü Başkanlığı kurulmuştur. Tüm bu düzenlemelere yön veren 7269 sayılı Afetler Kanunu'nun amacı, doğal afet sonrasında meydana gelecek durumlara yönelik kamunun müdahalesine imkan tanımaktır. Bu doğrultuda, valilik ve kaymakamlıklara özel yetkiler vererek, koordinasyonun ve kaynakların tek otoriteden seferber edilmesini sağlanmaktadır. Böylelikle, yalnızca doğal afetin meydana geldiği ve etkilenen bölgelerdeki kayıpların giderilmesi için çıkarılan tekil kanunların yerini tüm ülke 
genelinde afet koşullarında yapılacakları yönlendiren bir yasal zemin oluşturulmuştur. Ancak, Afetler Kanunu, uluslararası platformda geliştirilen ve yeni afet paradigmasının temelini oluşturan afet riski azaltma anlayışını geliştirilememesi ve kentsel riskleri azaltıcı rol oynayamaması nedeniyle güncel koşulları yakalamakta yetersiz kalmıştı. Kanun afet sonrasında meydana gelebilecek koşulların yönetilmesine dair bir çerçeve sunmakta olup, yalnızca afet sonrası koşulların tarif edilmesi nedeniyle risk yönetimi açısından noksan kalmıştır.

Öte yandan, Türkiye'de afet planlamasını mekansal gelişim planlarına entegre edecek yasal dayanak olan 3194 sayılı "Imar Kanunu" 1985 tarihinde yürürlüğe girmiştir. Afet yönetimi açısından incelendiğinde, İmar Kanunu'nda kentsel sakınım planları hazırlanmasını zorunlu kılan bir yasal ve örgütsel yapının varlığından söz edilemez. Bu geleneksel imar sistemi anlayışıyla, kent planlamasının ekonomik, sosyal ve fiziki boyutlarının entegre edildiği güncel bir yönetim biçimi veya afetlere ilişkin girişimlerde toplum kesimlerinin katılımını sağlayacak düzenlemeler gereği yerine gelememektedir.

1999 Depremlerinden önce, afet mevzuatının genel hatlarını çizen 7269 sayılı Afetler Kanunu ve 3194 sayılı İmar Yasası afet risklerini azaltmayı sağlayacak altyapıyı sunmakta zayıf kalmıştır; bu nedenle kentsel risklerin azaltılmasında mekansal planlamanın sağlayacağı olanaklardan faydalanılamamış ve depremler bu yasal zemine sahip bir ülkede meydana gelmiştir. Her iki yasa da afet risklerinin azaltılmasında planlamaya tanımlı rol vermemektedir. Oluşan boşluk, 2005 tarihli 5302 sayılı "II Özel İdaresi Kanunu”, 5216 sayıll "Büyükşehir Belediyesi Kanunu" ve 5393 sayllı "Belediye Kanunu" yoluyla yerel yönetimlere afetler konusunda yetki verilerek doldurulmaya çalışımıştır. Bahsi geçen kanunlarla afet öncesi ve sonrası dönemlerde belediyelere verilen sorumluluklar artırılmıştır. Kentsel dönüşüm yapma yetkilerinin yanı sıra çeşitli araç ve kaynaklara sahip olan yerel yönetimler kentsel riskleri azaltmak için uzun erimli ve kapsamlı çözümler geliştirmekte zayıf kalabilmiştir.

\section{Depremlerinin Ardından Planlama Mevzuatı}

Ülkenin nüfusu en yüksek, en kentleşmiş ve sanayileşmiş bölgesi olan Marmara Bölgesi'nde yaşanan 1999 Depremlerinin ardından geniş ölçekli iyileştirme çalışmaları başlatılmış, merkezi ve yerel yönetimlerin yanı sıra pek çok kurum ve sivil toplum bu çalışmaların parçası haline gelmiştir. 17 Ağustos 1999 Marmara Depreminin hemen ardından başlayan afete müdahale ve afet sonrası yardımları düzenleme ve afet zararlarını giderme çalışmalarını yürütebilmek için 29.08.1999 tarihinde 4452 sayılı "Doğal Afetlere Karşı Alınacak Önlemler ve Doğal Afetler Nedeniyle Doğan Zararların Giderilmesi İçin Yapılacak Düzenlemeler Hakkında Yetki Kanunu" çıkarılmıştır. Bu yetki kanununa dayanarak, depremin yol açtığı yıkıcı etkileri giderebilmek ve depremden etkilenen alanlarda yapılacak işlemleri düzenleri düzenlemek ve yardımları etkinleştirmek üzere bir yıllık süre içinde 29 kanun hükmünde kararname (KHK) çıkarılmıştır (Tablo 2). Bu KHKlar vergilendirme, sosyal hizmetler, yeniden yerleştirme, kurumların görevlendirilmesi, sigortalama, borç erteleme, il ve büyükşehir belediyesi statüsü kazandırma, yapı denetimi ve mesleki yeterlilikler gibi geniş bir yelpazede afet sonrasındaki işleyişi düzenlenme amacı taşmaktadır.

Afet sonrasında kısa vadede harekete geçmeyi ve toplumsal işleyişe yeniden sağlayan eylemleri yönlendiren yasal düzenlemelerin büyük kısmı risk azaltma hedefini gözeterek oluşturulmamışır. Çağdaş afet paradigmaları toplumların afet öncesindeki kırılgan yapısının yeniden üretilmesinin aksine, iyileştirme politikalarıly güvenli bir kentsel ve toplumsal yapının üretimine katkı koymasını gerekli kılmıştır. Özellikle, 1999 Depreminin yıkıcı etkilerinin ardından bu gereklilik açıkça görülmüş ve afet politikalarını yönlendiren yasal çerçevenin kısıtlılı̆ı anlaşıldığından bu alanda önemli adımlar atılmışır.

Türkiye'de 2009 yllına kadar afet yönetimi sisteminin kurumsal yapısını Başbakanlık, Bayındırlık ve İskan Bakanlı̆̆ı ile İçişleri Bakanlığı'na bağlı birimler oluşturmuştur. Bu yetkili kurumların dışında farklı idarelere tabi müdürlük, kurul, koordinatörlük ve merkezler de çeşitli sorumluluklar sahibidir. 29.05.2009 tarih ve 5902 sayılı yasayla Başbakanlık Acil Durum Yönetimi Genel Müdürlüğü, Bayındırlık ve İskan Bakanlığı Afet İşleri Genel Müdürlüğü ve İçişleri Bakanlığı Sivil Savunma Genel Müdürlüğü kaldırılarak yerine Başbakanlığa bağı "Afet ve Acil Durum Yönetimi Başkanlı̆̆ı" (AFAD) kurulmuştur. Bu sayede, afet yönetiminin tek çatı altında toplanması ve koordinasyonun tek merkezden yürütülmesi amaçlanmıştır. İllerde, il özel idaresi bünyesinde, valiye bağı il afet ve acil durum müdürlükleri kurulmuştur. Bu müdürlüklerinin görevleri, ilin afet ve acil durum tehlike ve risklerini belirlemek, önleme ve müdahale il planlarını mahalli idareler ile kamu kurum ve kuruşlarıyla işbirliği ve koordinasyon içinde yapmak ve uygulamak olarak belirlenmiştir. Yerel düzeyde ise belediyelere afet öncesi ve sonrası düzenleme yapma yetkileri verilmiştir.

Kurumsal örgütlenmelerdeki yeni yapılanmanın yanı sıra, son 20 yılda mevzuatta da afet yönetimine ilişkin düzenlemelere gidilmiştir. Bu dönemde, yerel ve merkezi yönetimlerin kurumsal yapısını biçimlendiren kanunlar yürürlüğe girerek, kurumların afet yönetimindeki rol ve sorumlulukları tanımlanmıştır. Risk azaltma amacıyla son 20 yılda kentsel planlama mevzuatıyla da doğrudan ilişkili olan yasal düzenlemelerin başında 5393 sayılı "Belediye Yasası"nın 73. Maddesi, 5366 sayılı "Yıpranan Tarihi ve Kültürel Taşınmaz Varlıkların Yenilenerek Korunması ve Yaşatılarak Kullanılması Hakkında Kanun”, 6306 sayılı "Afet Riski Altındaki Alanların Dönüştürülmesi Hakkında Kanun" ve 3194 Sayılı "İmar Kanununun 
Tablo 2. 1999 depremleri sonrası afet yönetimine ilişkin kanun ve KHK düzeyindeki yasal düzenlemeler

\begin{tabular}{|c|c|c|}
\hline Tarih & Sayı & Kanun adı \\
\hline 99 & 452 & $\begin{array}{l}\text { Doğal Afetlere Karşı Alınacak Önlemler ve Doğal Afetler Nedeniyle Doğan Zararların Giderilmesi İçin Yapılacak } \\
\text { Düzenlemeler Hakkında Yetki Kanunu }\end{array}$ \\
\hline 1999 & 574 & $\begin{array}{l}\text { Umumî Hayata Müessir Afetler Dolayısıyla Alınacak Tedbirlerle Yapılacak Yardımlara Dair Kanunda Değişiklik Yapılması } \\
\text { Hakkında Kanun Hükmünde Kararname }\end{array}$ \\
\hline 1999 & 575 & $\begin{array}{l}\text { Doğal Afet Bölgelerinde Afetten Kaynaklanan Hukukî Uyuşmazlıkların Çözümüne ve Bazı İşlemlerin Kolaylaştırılmasına } \\
\text { illişkin Kanun Hükmünde Kararname }\end{array}$ \\
\hline 1999 & 576 & $\begin{array}{l}\text { Doğal Afetlerde Yapılacak Yardımların Düzenlenmesi ile Vergilerin Ödeme Sürelerinin Uzatılmasına ve Bazı Kanunlarda } \\
\text { Değişiklik Yapılmasına Dair Kanun Hükmünde Kararname }\end{array}$ \\
\hline 1999 & 577 & $\begin{array}{l}\text { Umumî Hayata Müessit Tabii Afetler Dolayiyle Alınacak Tedbirlerle Yapılacak Yardımlara Dair Kanuna Bir Geçici Madde } \\
\text { Eklenmesi Hakkında Kanun Hükmünde Kararname }\end{array}$ \\
\hline 1999 & 578 & Bazı Kanunlarda (506, I479, 2926, ve7269 Sayılı Kanunlar) Değişiklik Yapılması Hakkında Kanun Hükmünde Kararname \\
\hline 1999 & 579 & $\begin{array}{l}\text { Millî Piyango Genel Müdürlüğü Kuruluş ve Görevleri Hakkında KHK'ye Bir Madde Eklenmesine Dair Kanun Hükmünde } \\
\text { Kararname }\end{array}$ \\
\hline 1999 & 580 & $\begin{array}{l}\text { Umumî Hayata Müessir Afetler Dolayisiyle Alınacak Tedbirlerle Yapılacak Yardımlara Dair Kanuna Geçici Maddeler } \\
\text { Eklenmesi Hakkında Kanun Hükmünde Kararname }\end{array}$ \\
\hline 1999 & 581 & $\begin{array}{l}\text { Umumî Hayata Müessir Afetler Dolayısiyle Alınacak Tedbirlerle Yapılacak Yardımlara Dair } 7269 \text { Sayılı Kanun ile Mera } \\
\text { Kanunu, Muhasebe-i Umumiye Kanunu, 2886Sayılı Kanun ile İçişleri Bakanlığı Teşkilât ve Görevleri Hakkında Kanunlarda } \\
\text { Değişiklik Yapılması Hakkında Kanun Hükmünde Kararname }\end{array}$ \\
\hline 1999 & 582 & Afetten Doğan Zararların Giderilmesi Hakkında Kanun Hükmünde Kararname \\
\hline 1999 & 583 & $\begin{array}{l}\text { Başbakanlık Teşkilatı Hakkında Kanun Hükmünde Kararnamenin Değiştirilerek Kabulü Hakkında Kanunda Değişiklik } \\
\text { Yapılmasına Dair Kanun Hükmünde Kararname }\end{array}$ \\
\hline 1999 & 584 & $\begin{array}{l}\text { Düzce Adı ile Bir İI ve Bu İle Bağı olarak İki İlçe Kurulması ile } 190 \text { Sayılı KHK`nin Eki Cetvellerde Değişiklik Yapılması } \\
\text { Hakkında Kanun Hükmünde Kararname }\end{array}$ \\
\hline 1999 & 585 & klenmesi Hakkında Kanun Hükmünde Kararname \\
\hline 1999 & 586 & nda Değişiklik Yapılmasına D \\
\hline 1999 & 587 & Deprem Sigortasına Dair Kanun Hükmünde Kararname \\
\hline 1999 & 588 & Konut Edindirme Yardımı Hesalarının Tasviyesine Dair Kanun Hükmünde Kararname \\
\hline 2000 & 589 & $\begin{array}{l}\text { Emekli Sandığı Kanunu ile Bazı Kanunların Doğal Afetlerle İlgili Maddelerinde Değişiklik Yapılmasına Dair Kanun Hükmünde } \\
\text { Kararname }\end{array}$ \\
\hline 2000 & 590 & $\begin{array}{l}\text { Tapulama ve Kadastro Paftalarının Yenilenmesi Hakkında Kanuna Bazı Maddeler Eklenmesine Dair Kanun Hükmünde } \\
\text { Kararname }\end{array}$ \\
\hline 2000 & 591 & $\begin{array}{l}\text { Ticaret ve Sanayi Odaları, Ticaret Odaları, Sanayi Odaları, Deniz Ticaret Odaları, Ticaret Borsaları ve Türkiye Ticaret, } \\
\text { Sanayi, Deniz Ticaret Odaları ve Ticaret Borsaları Birliği Kanununa Bir Geçici Madde Eklenmesi Hakkında Kanun Hükmünde } \\
\text { Kararname }\end{array}$ \\
\hline 2000 & 592 & gortalar Kanunu ile 4447 Sayılı Kanunda Değişiklik Yapılmasına Dair Kanun Hükmünde Kararname \\
\hline 2000 & 593 & Sakarya İlinde Büyük Şehir Belediyesi Kurulması Hakkında Kanun Hükmünde Kararname \\
\hline 2000 & 594 & $\begin{array}{l}\text { Sosyal Hizmetler ve Çocuk Esirgeme Kurumu Kanununda ve } 190 \text { Sayılı Kanun hükmünde Kararname Eki Cetvellerde } \\
\text { Değişiklik Yapılması Hakkında Kanunu Hükmünde Kararname }\end{array}$ \\
\hline 2000 & 595 & Yapı Denetimi Hakkında Kanun Hükmünde Kararname \\
\hline 2000 & 596 & Sivil Savunma Kanununda Değişiklik Yapılmasına Dair Kanun Hükmünde Kararname \\
\hline 2000 & 597 & $\begin{array}{l}\text { Umumi Hayata Müessir Afetler Dolayısiyle Alınacak Tedbirlerle Yapılacak Yardımlara Dair Kanuna Bir Geçici Madde } \\
\text { Eklenmesi Hakkında Kanun Hükmünde Kararname }\end{array}$ \\
\hline 2000 & 598 & $\begin{array}{l}\text { Umumî Hayata Müessir Afetler Dolayısiyle Alınacak Tedbirlerle Yapılacak Yardımlara Dair Kanunun Bazı Maddelerinin } \\
\text { Değiştirilmesi ile Bir Geçici Madde Eklenmesi Hakkında Kanun Hükmünde Kararname }\end{array}$ \\
\hline 2000 & 599 & $\begin{array}{l}\text { Umumî Hayata Müessir Afetler Dolayısiyle Alınacak Tedbirlerle Yapılacak Yardımlara Dair Kanunun 3. Maddesinin } 3 . \\
\text { Fıkrasında Değişiklik Yapılması Hakkında Kanun Hükmünde Kararname }\end{array}$ \\
\hline 2000 & 600 & $\begin{array}{l}\text { Başbakanlık Teşkilatı Hakkında Kanun Hükmünde Kararnamenin Değiştirilerek Kabulü Hakkında Kanunda Değişiklik } \\
\text { Yapılmasına Dair Kanun Hükmünde Kararname ile Türkiye Acil Durum Yönetimi Genel Müdürlüğü kurulması }\end{array}$ \\
\hline 2000 & 601 & Mühendislik ve Mimarlık Hakkında Kanun ile Türk Mühendis ve Mimar Odaları Birliği Kanununda Değişiklik Yapılmasına \\
\hline
\end{tabular}


Tablo 2 (devamı). 1999 depremleri sonrası afet yönetimine ilişkin kanun ve KHK düzeyindeki yasal düzenlemeler

\begin{tabular}{|c|c|c|}
\hline Tarih & Sayı & Kanun adı \\
\hline & & Dair Kanun Hükmünde Kararname \\
\hline 2000 & 603 & $\begin{array}{l}\text { Düzce Adıyla Bir İ ve İki İlçe Kurulması Hakkında (584 Sayılı) Kanun Hükmünde Kararname ile Sakarya İlinde Büyükşehir } \\
\text { Belediyesi Kurulması Hakkında (593 Sayıı) Kanun Hükmünde Kararnamede Değişiklik Yapılmasına Dair Kanun Hükmünde } \\
\text { Kararname }\end{array}$ \\
\hline 2001 & 4708 & Yapı Denetimi Hakkında Kanun Hükmünde Kararname \\
\hline 2004 & 5216 & Büyükşehir Belediyesi Kanunu \\
\hline 2005 & 5302 & İl Özel İdaresi Kanunu \\
\hline 2005 & 5366 & Yıpranan Tarihi ve Kültürel Taşınmaz Varlıkların Yenilenerek Korunması ve Yaşatılarak Kullanılması Hakkında Kanun \\
\hline 2005 & 5393 & Belediye Kanunu \\
\hline 2009 & 5902 & Afet ve Acil Durum Yönetimi Başkanlığı'nın Teşkilat ve Görevleri Hakkında Kanun \\
\hline 2011 & 644 & Çevre ve Şehircilik Bakanlığının Teşkilat ve Görevleri Hakkında Kanun Hükmünde Kararname \\
\hline 2012 & 6305 & Afet Sigortaları Kanunu \\
\hline 2012 & 6306 & Afet Riski Altındaki Alanların Dönüştürülmesi Hakkında Kanun \\
\hline
\end{tabular}

Kaynak: Aktel, 20I0; Ergünay, 20II; Kemaloğlu, 20I5; Kepenek ve Gençel, 20I6; Tercan, 20I8; URL-I, 2021.

Geçici 16. Maddesi (İmar Barışı)" gelmektedir. Bu kanunlar, afet riski azaltmada mekansal planlama yoluyla müdahale etme araçlarını tanımlaması bakımından kentsel planlamaya afet yönetiminde rol biçmektedir. Bu nedenle, günümüz afet yönetiminin temel ayağı olan kentsel riskleri azaltmada yasal çerçeveyi belirleyen bu kanunlara ve kanunların ilgili maddelerine ayrıntılı olarak yer verilecektir.

İlk olarak incelenen, 2005 tarihli 5393 sayılı Belediye Yasası'nın 73. Maddesi'nde kentsel dönüşüm yapma yetkisi belediyelere verilmiştir. Bu yasa uyarınca belediyeler kentsel dönüşüm ve gelişim alanı ilan etme ve imarlı ve imarsız alanda dönüşüm ve gelişim proje alanı belirleme yetkisi kazanmıştır. 2010 yılında 5998 sayılı Belediye Kanununda Değişiklik Yapılmasına İlişkin Kanun ile 5393 sayılı kanunun 73. Maddesi "Büyükşehir belediye ve mücavir alan sınırları içinde kentsel dönüşüm ve gelişim projesi alanı ilan etmeye büyükşehir belediyeleri yetkilidir" olarak değiştirilmiş; buna göre dönüşüm yetkisi ilçe belediyelerinden büyükşehir belediyelerine aktarılmıştır. Kanuna göre, belediyeler "konut alanları, sanayi alanları, ticaret alanları, teknoloji parkları, kamu hizmeti alanları, rekreasyon alanları ve her türlü sosyal donatı alanları oluşturmak, eskiyen kent kısımlarını yeniden inşa ve restore etmek, kentin tarihi ve kültürel dokusunu korumak veya deprem riskine karşı tedbirler almak amacıyla kentsel dönüşüm ve gelişim projeleri uygulayabilir". Yasa ile en az 5 hektarlık bir alanda proje yapılması şartı bulunmaktadır. Bu yasaya yönelik geliştirilen eleştirilerin başında mülk sahiplerinin sürece katılmalarına ilişkin düzenlenmelerin tanımlanmamış olması ve yapılan dönüşüm projelerinde üst ölçekli planlara uyma şartının aranmayacak olması gelmektedir (Karaaslan, 2016). Benzer şekilde, dönüşümün nasıl gerçekleşeceğine ilişkin bir yol haritasının olmadığı, bir yerin dönüşüm alanı olmasının alan büyüklüğüne şartına bağlandığı da eleştiri konusudur.
2005 yılında çıkarılan 5366 sayılı Yıpranan Tarihi ve Kültürel Varlıkların Yenilenerek Korunması ve Yaşatılarak Kullanılması Hakkında Kanun ile sit alanlarında kentsel dönüşüm ve yenileme olanaklı kılınmıştır. Bu yasa ile yıpranan, özelliğini kaybetmeye yüz tutmuş, sit alanı olarak tescil ve ilan edilen bölgelerde, belediyelerin yetkisinde kentsel yenileme uygulamalarının önü açılmıştır. Yasaya göre, yeniden inşa ve restorasyon yoluyla korunan alanlarda konut, ticaret, kültür, turizm, sosyal donatı alanı oluşturmak ve doğal afet riskine karşı önlem almak amaçlanmıştır. Yenileme alanları il genel meclisi veya belediye meclisinin salt çoğunluk kararı ile belirlenmektedir. Kanuna yönelik eleştirilerin başında sit alanlarında yıkım yeniden inşa etmeye izin verilmesi, imar koşullarını yeniden düzenleyerek soylulaştırmanın önünün açılması, sit alanı statüsünün kaybı, mülkiyete kamulaştırma yoluyla müdahale edilmesi ve katıIım süreçlerinin idarenin inisiyatifine bırakılması gelmektedir (Ahunbay vd., 2016). Öte yandan, yıpranan bölgeyi belirleme ölçütlerinin somut olarak tanımlanmamış olması ve koruma amaçlı imar planlarına karşı tutumun belirsizliği konuları da gündeme getirilmiştir (Daşkıran ve $A k, 2015)$.

Kentsel planlamada afetlere yönelik en tanımlı yasa olan 6306 sayılı Afet Riski Altındaki Alanların Dönüştürülmesi Hakkında Kanun 2012 yılında yürürlüğe girmiştir. Kanun, riskli alanlarda sağııkı ve güvenli yaşam çevresi oluşturulması hedefi taşıyan bir kentsel dönüşüm yasası niteliğindedir. Kanun, "afet riski altındaki alanlar ile bu alanlar dışındaki riskli yapıların bulunduğu arsa ve arazilerde, fen ve sanat norm ve standartlarına uygun, sağııkı ve güvenli yaşama çevrelerini teşkil etmek üzere iyileştirme, tasfiye ve yenilemelere dair usul ve esasları belirlemek" amacı taşımaktadır. Kanuna göre, kentsel dönüşüme tabi olacak üç yapı türü belirlenmiştir; ekonomik ömrünü tamamlamış yapı, ağır hasar görme riski tespit edilen yapı ve yıkılma riski taşıdığı tespit edilen yapı. Bunlara ek olarak uygulama bütünlüğü 
gereği belirlenen alanların sınırları içinde olup riskli yapı dışında kalan yapılarda kanun hükümlerine tabi tutulmuştur. Bu kanunla birlikte Çevre ve Şehircilik Bakanlığı riskli alanlarda plan yapma, yaptırma ve onaylamada yetkili idare olarak tanımlanmıştır. Riskli yapıların tespiti lisanslı kurumlarca maliklerin veya idarenin talebiyle yapılıp, yıkım gereği ortaya çıktığı durumda idare ve maliklerin anlaşması esas alınarak 60 gün içinde yıkım gerçekleştirilir ve anlaşan hak sahibine kira yardımı veya konut ya da işyeri tahsisi yapılır. Yasanın temelde getirdiği yeni uygulamaların başında dönüşümün belli bir alan yerine tek bir yapıda uygulanabilirliği gelmektedir. Böylelikle, eskiyen ve riskli hale gelen konut stokunun tekil uygulamalarla yeniden inşa edilmesinin önü açılmıştır. Yasayla birlikte Bakanlık elinde toplanan yetkilerle birlikte merkezileşmenin ortaya çıktığı görülmektedir; ancak bu durumda, kanun, merkezi yönetime kanunun hazırlayıcı ve uygulayıcısı rolünün yanı sıra denetleyicisi de olma görevi vermesi bakımından eleştirilmektedir (Daşkıran ve Ak, 20I5). Öte yandan, uygulama bütünlüğü nedeniyle risk taşımayan yapılarında kanun kapsamında kentsel dönüşüme tabi olması ve haklarında yıkım kararı verilebilecek olması yönünden mülkiyet hakları konusunu gündeme getirmiştir. Ek olarak, hak sahipleri ile anlaşamama durumunda acele kamulaştırma yolunun açılması ve kamulaştırma bedelinin gayrimenkulün dönüşüm öncesi niteliklerine göre belirlenmesi, mülk sahipleri bakımından seçeneksizlik sorununa yol açabileceği yönünden eleştiri konusudur. Diğer bir deyişle, kanunun hak sahiplerinin rızası ve katılımcılık açılarından geliştirilmesi gereklidir.

Bu dönüşüm ve yenileme içerikli kanunların yanı sıra 2004 yılında 5104 sayılı "Kuzey Ankara Kent Girişi Kentsel Dönüşüm Projesi Kanunu” çıkarılmıştır. Bu kanun, Ankara'nın kuzey kent girişi bölgesinde yer alan konut alanlarının dönüşümle birlikte fiziki durumunun ve çevre görüntüsünün geliştirilmesi, güzelleştirilmesi, sağıılaştırılması ve yaşam kalitesinin artması amacı taşımaktadır. Kanunla belirlenen dönüşüm alanındaki ilçe belediyelerinin yetkileri büyükşehir belediyesine devredilmiş ve TOKi iştiraki ile projenin gerçekleştirilmesi hedeflenmiştir. Bu kanun her ne kadar afet riskleri odaklı bir çıkış noktasına sahip olmasa da kentsel dönüşüm araçlarından birini tanımlaması bakımından göz önüne alınması gereklidir.

Son olarak ise 2018 yılında 7|43 sayılı Kanunla birlikte 3194 sayılı İmar Kanuna Geçici 16. Madde eklenmiş ve buna göre afet risklerine hazırlık kapsamında ruhsatsız veya ruhsat ve eklerine aykırı yapıların kayıt altına alınması ve imar barışının sağlanması amacıyla 3 I/I2/2017 tarihinden önce yapılmış yapılar için yapı kayıt belgesi verilebileceği konusu düzenlenmiştir. Bu düzenleme ile Boğazici Sahil Şeridi ve öngörünüm bölgesi ile İstanbul Tarihi Yarımada, Gelibolu Tarihi Alanı, başkasına ait taşınmazlar üzerinde yapılan yapılar ile hazineye ait olup sosyal donatı için tahsisli arazi üzerindeki yapılar dışında kalan kırsal ve kentsel alanlardaki tüm yapılar İmar Barışı kapsamına alınmıştır. Yapı kayıt belgesi alan yapılara geçici olarak su, elektrik ve doğalgaz bağlanabilir ve haklarında alınmış yıkım kararları ile tahsil edilemeyen idari para cezaları iptal edilir. Yapı maliki tarafından müracaatı yapılan ve bedeli ödenen Yapı Kayıt Belgesi ile yapıya ilişkin cins değişikliği ve kat mülkiyeti gerçekleştirilebilir, her türlü bankacılık işlemlerinde değerlendirilebilir ve Hazine taşınmazı üzerindeki yapılar arsalarını rayiç bedel üzerinden satın alabilir (ÇŞB, 20I9). Bu belge, yapının yeniden yapılmasına veya kentsel dönüşüm uygulamasına kadar geçerli görülmektedir. İmar Barışı olarak bilinen kanun maddesinin uygulanmasına ilişkin usul ve esaslar Çevre ve Şehircilik Bakanlığı tarafından belirlenir. İmar Barışı düzenlemesi, kapsamı açısından oldukça büyük bir yapı stokunu, farklı işlevlere sahip yapıları ve her türde arazi kullanımını içermektedir. Bu uygulama her ne kadar afet risklerine hazırlık gayesine sahip olsa da riskli bölgelerdeki yapıları veya riskli yapıları ruhsatsız olmaktan kurtararak kayıtlı ve kullanılabilir hale getirmiştir. Bu durum, daha önce çıkarılan kentsel yenileme ve dönüşüm kanunlarıyla disipline edilmeye çalışılan risk önleme çabalarıyla çelişme olasılığı yaratmaktadır. Özellikle 6306 sayılı yasayla afet riski taşıdı̆ı tespit edilen yapılara ilişkin yıkım kararı verilmesi gündeme gelmesine rağmen, yapı kayıt belgesi başvuru ve taleplerinde afete karşı dayanıklılığa ilişkin bir tespitin yapılması beklenmemektedir. Böylece, olası riskli yapılar için belirli bir tarihe ilişkin denetim yapma işlemi dile getirilmediğinden tedbir alma konusunun maliklerin tasarrufuna bırakıldığı görülmektedir (Balamir, 2019). "Kentsel dönüşüme girilmesine kadar" ifadesiyle ortaya konulan süre tanımı kayıt belgesi edinmiş riskli yapının yıkımının sürecini belirsizleştirmektedir. Öte yandan, taşkın sahası, fay hatları, heyelan bölgeleri, kıyı, havza, sulak alanlar ile tarım sahaları gibi riskli alanlarda yer alan yapıların İmar Barışı kapsamına alınması ve Hazine arazilerinin satışıyla özel mülkiyete geçerek yapılaşmaya konu olması güvenli bir çevrenin oluşumunda sorunlara yol açabilecektir.

Sonuç olarak, kırdan kente yapılan hızlı göçler ve sınırlı yapı üretim kapasitesiyle niteliksiz bir yapılaşma eğilimine sahip ve yapı stokunun büyük kısmı eski mevzuata göre inşa edilmiş kentlerde afetlere karşı dirençli ve güvenli bir yaşam çevresinin oluşturulması kentsel müdahaleleri gerekli kılmaktadır. Kent planlamanın bu müdahaleleri gerçekleştirebilme araçlarını özellikle 1999 Depreminin peşinden yürürlüğe giren mevzuat şekillendirmektedir. Planlama standartlarının, yapı denetimlerinin ve afet sigortalarının yetersiz olduğu kentsel çevrelerde afetlere ilişkin alınacak tedbirlerin başında kapsamlı kentsel yenileme politikaları gelmektedir. Bu bakımdan, planlamaya yön veren güncel mevzuatın kentsel dönüşümü esas aldığı, sağlıksız yapı stokunun tespit edilerek müdahale yaklaşımının belirlendiği, yetkinin merkezi ve yerel idarelerce kullanıldığı görülmektedir. Ancak, bu kanunlar uyarınca yapılan uygulamaların ve gerçekleşen projelerin fiziki müdahale ile sınırlı kalması, yaşayanların sosyal ve ekonomik problemlerini çözme araçlarını tarif etmemesi afet riski azaltma amaçlı kentsel dönüşüm mevzuatının eleştirilere konu olmasına yol açmaktadır. 


\section{Tartışma}

1999 Depremlerinin ardından en temel değişim adımı AFAD Başkanlığı'nın kurulması olarak görülmektedir. Afet yönetiminde örgüt karmaşasının önlenerek yönetimin tek elden yürütülmesi olumlu bir gelişme olmakla birlikte afet yönetiminin yalnızca merkezi yönetimin yetki ve sorumluluk alanında görülmesi özellikle kentsel risklerin azaltılması için tek başına yeterli olmayacaktır. Uluslararası politikaların gereği olarak afet yönetiminde çok yönlü bir kurumsallaşmaya gereksinim vardır. Bu yenilikçi yapı, merkezi ve yerel yönetimlerin yanı sıra sivil toplum kuruluşlarını, meslek odalarını, iş ve akademi çevrelerini, medyayı ve toplum önderlerini kapsamalıdır. Ancak, en önemli bileşenlerden birisi de afet riski azaltımında toplumun katılımı ve karar verici olmasıdır; bu sayede geniş bir tabanda kabul gören, benimsenen ve uygulanan bir afet yönetimi ve risk azaltımı gerçekleşebilecektir.

Kurumsal yapıdaki önemli değişimin yanı sıra kent planlamayı ilgilendiren mevzuatta da son 20 yılda gelişmeler görülmektedir. Özellikle, 1999 Depremlerine değin her büyük doğal afet sonrasında ortaya çıkan acil duruma müdahale etmek ve afet sonrası iyileştirme döneminde yapılacak işlemleri yürütmek amacıyla akut, tekil yasal düzenlemelerin devreye girdiği görülmektedir. 1999 Depremlerinin ardından müdahale ve iyileştirme dönemlerine dair peş peşe ve geniş bir yelpazede sunulan kanun hükmünde kararnameler çıkarılarak toplumsal işleyişin devam etmesi amaçlanmıştır. Afetin toplumun hemen her alanında yol açtığı kesintinin büyüklüğü göz önüne alındığında, kamusal seferberliğin afet risklerini azaltmaya doğru yönlendirilmesi gerekliliği ortaya çıkmıştır. Çağdaş afet yönetimi anlayışına paralel olarak, afet yönetimine yönelik atılan yasal düzenlemelerdeki adımların ortak amacı açıkça risk azaltımı ve güvenli bir kentsel çevrenin oluşturulması olarak tanımlanmıştır. Bu amaç doğrultusunda afet riski azaltma müdahalelerinin başlıca aracı olarak kentsel dönüşüm sunulmuş ve çeşitli yasal düzenlemelerle güvensiz kentsel yerleşimlerin dönüştürülmesi görevi yerel ve merkezi yönetimlere bırakılmıştır.

Mevzuattaki yeni gelişmeler afet yönetiminde temel ve büyük bir açığın giderilmesinde önemli girişimler olmakla birlikte, riskli alanların önceliklendirilmesi, uygulamaların kanunların amaçlarıyla bütünlük taşıması ve toplumu afet yönetimi bakımından disipline etmesi konularında izlenmeleri gerekmektedir. Bu süreçlerin izleme ve değerlendirilmelerinde varsa uygulama ile çelişen, zayıf veya eksik noktaların giderilmesi, kanunun amacıyla uygulama tutarlılığın denetlenmesi ve güncel afet yönetimi yaklaşımları uyarınca güncellenmeleri gerekmektedir. Ayrıca, kent planlaması ve afet yönetimi arasındaki ilişkiyi kuracak ve afet öncesinde yapılacakları denetim altında tutacak araçları tanımlayan önlemlere ilişkin güncel mevzuatın oluşturulması sağlıklı ve dirençli bir kentsel gelişmenin koşuludur.

\section{KAYNAKLAR}

Ahunbay, Z., Dinçer, İ., ve Şahin, Ç. (2016). Neoliberal kent politikaları ve Fener-Balat-Ayvansaray: bir koruma mücadelesinin öyküsü. Türkiye İş Bankası Kültür Yayınları, İstanbul.

Aktel, M. (2010). 5902 sayılı yasa ile Türkiye'de afet yönetiminde oluşan değişim. Dumlupınar Üniversitesi Sosyal Bilimler Dergisi, 27, 169-180.

Balamir, M. (2007). Risk Yönetimi ve Yerel Yönetimler, içinde. N. Ekin-Erkan, A. Guner, K. Demeter, Afet Risk Yönetimi: Risk Azaltma ve Yerel Yönetimler, Marmara Universitesi ve Dünya Bankası, Beta Yayıncilı, Istanbul.

Balamir, M. (2012). Afetlere ilişkin planlama etkinlikleri ve sakınım planlaması, içinde Ersoy, M. (der.) Kentsel Planlama Ansiklopedik Sözlük, Ninova Yayıncilik, İstanbul, s. 2-6.

Balamir, M. (2019). Plancının Kassandra Yazgısı: Afetler, Kentler, Yasal ve Kurumsal Yapılanma, TMMOB Şehir Plancıları Odası Yayınları: Ankara.

Balamir, M. ve Orhan, E. (2012). Uluslararası Afet Politikaları, içinde Ersoy, M. (der.) Kentsel Planlama Ansiklopedik Sözlük, Ninova Yayıncılık, İstanbul, s. 457-460.

Bang, H.N. (2014). General overview of the disaster management framework in Cameroon. Disasters, 38(3), 562-586.

Bolin, R. ve Stanford, L. (1998). The Northridge Earthquake: Vulnerability and Disaster, Routledge, New York.

Burby, R.J. ve Dalton, L.C. (1994). Plans can matter! The role of land use plans and state planning mandates in limiting the development of hazardous areas. Public administration review, 229-238.

Burby, R.J., Nelson, A.C., Parker, D. ve Handmer, J. (2001). Urban containment policy and exposure to natural hazards: is there a connection?. Journal of Environmental Planning and Management, 44(4), 475-490.

ÇŞB- Çevre ve Şehircilik Bakanlığı (2019). İmar Barışı Broşürü, web sitesi: https://webdosya.csb.gov.tr/db/imarbarisi/icerikler/brosur20180603111057.pdf, son erişim 05.09.2019

Daşkıran, F. ve Ak, D. (2015). 6306 sayılı Kanun Kapsamında Kentsel Dönüşüm. Yönetim ve Ekonomi Araştırmaları Dergisi, 13(3), 264-288.

Dalton, L.C. ve Burby, R.J. (1994). Mandates, plans, and planners: Building local commitment to development management. Journal of the American Planning Association, 60(4), 444-461.

Ergünay, O. (2011). 1999 Depremleri Afet Mevzuatını Nasıl Değiştirdi: Mevzuat Açısından Neredeyiz?, 1. Türkiye Deprem Mühendisliği ve Sismoloji Konferansı Bildiriler Kitabı, 11-14 Ekim 2011, ODTÜ, Ankara

Godschalk, D.R., Kaiser, E.J., ve Berke, P.R. (1998). Integrating hazard mitigation and local land use planning, İçinde Burby,R.J. (der) Cooperating with nature: Confronting natural hazards with land-use planning for sustainable communities, 85-118.

Johnson, C. (2011). Creating an enabling environment for reducing disaster risk: Recent experience of regulatory frameworks for land, planning and building in low and middle-income countries, Global Assessment Report on Disaster Risk Reduction - GAR 2011.

Karaaslan, Ş. (2016). Türkiyéde Kentsel Dönüşüm Süreci ve Güncel Problemler, içinde Uğurlar, A., Erol, D., Öcalır Akünal, E.V., Erdoğanaras, F., Cihangir Çamur, K., Alkan, L., Görer Tamer, N., Yenigül, S.B., Duman Yüksel, Ü., Özdemir, Z. (der.) 80 Sonrası Mekan ve Planlama, Gazi Üniversitesi Mimarlık Fakültesi, Ankara, s. 345-355.

Kemaloğlu, M. (2015). Türkiyéde afet yönetiminin tarihi ve yasal gelişimi. Akademik Bakış Dergisi, 52, 126-147.

Kepenek, E. ve Gençel, Z. (2016). Türkiyéde Afet Zararlarını Azaltma Çalışmaları: Mevzuat Açısından Genel Bir Değerlendirme. Mimarlık Bilimleri ve Uygulamaları Dergisi, 1(1), 44-50.

Orhan, E. (2016). Reading urban vulnerabilities through urban planning history: An earthquake prone city case from Turkey, METU Journal of Faculty of Architecture, 33(2), 139-159.

Orhan, E. (2018). Tarihi Kent Merkezlerinin Kırılganlığı ve Afet Yönetimi 
Üzerine Bir Değerlendirme: Ankara Saraçlar Sokağı Yangını Örneği, İdealKent, 9(23), 189-215.

Rivera, C. ve Wamsler, C. (2014). Integrating climate change adaptation, disaster risk reduction and urban planning: A review of Nicaraguan policies and regulations, International Journal of Disaster Risk Reduction, 7, 78-90.

Smith, K., ve Petley, D.N. (2009). Environmental Hazards: Assessing Risk and Reducing Disaster, Routledge.

Tercan, B. (2018). Türkiyéde afet politikaları ve kentsel dönüşüm. Abant Kültürel Araştırmalar Dergisi, 3(5), 63-74.

UNISDR (United Nations International Strategy for Disaster Reduction). (2005). Hyogo framework for action 2005-2015: Building the resilience of nations and communities to disasters. World Conference on Disaster Reduction, 18-22 Ocak 2005, Kobe, Hyogo, Japonya.

UNISDR (United Nations International Strategy for Disaster Reduction). (2015). Sendai framework for disaster risk reduction 2015-2030. http:// www.wcdrr.org/uploads/Sendai_Framework_for_Disaster_Risk_Reduction_2015-2030.pdf. Son erişim Mart, 2021.

URL-1, http://anayasa.gen.tr internet sitesi, Kanun Hükmünde Kararnameler. Son erişim 25 Mart, 2021. 